\title{
MINUTES OF THE 25TH MEETING OF THE CANADIAN SOCIETY OF FOREST ENGINEERS HELD IN MONTREAL.
}

\author{
JANUARY 25th AND 26th.
}

Thursday morning, January 25 th, the meeting was called to order with Mr. Zavitz in the chair in the absence of the President.

The Secretary's report was presented and summarized and it was moved and seconded that this report be accepted. The minutes of the last annual meeting, which had already appeared in print in the February number of the Chronicle, were accepted.

The Treasurer then presented his report and it was moved and seconded that this be accepted (Copies of both these reports will be found elsewhere in this number).

Dr. Howe was then asked to present his paper entitled "Twenty-five Years in Retrospect and Some Suggestions for the Prospect." During the reading of this paper the President, Mr. Piché, arrived and took the chair. Following the reading of this Mr. Zavitz and Mr. Prince were called on to make their comments.

Mr. Zavitz in discussing the paper, indicated the intention of the Ontario government to embark on demonstration forest development. G. H. Prince, Deputy Minister of Lands and Forests of New Brunswick, stressed also the value of utilizing unemployment relief labour. He instanced the establishment of a forestry experimental area in New Brunswick by the Dominion Forest Service in cooperation with the province, and under the general scheme for rehabilitation of single unemployed men administered by the Department of National Defence of Canada.

The President then expressed his regret at not being on hand at the opening of the meeting and welcomed the members to Montreal, after which he made a few remarks regarding the present forestry situation.

Following this the resolutions committee was appointed, consisting of $\mathrm{Dr}$. Howe, Chairman, and Messrs. Prince, Cameron and Fensom.

A committee was also appointed to confer with the executive regarding Canadian Forestry Association affairs, the members named being Zavitz, Prince, Howe, Finlayson and Kennedy.

Mr. C. A. Hoar, of the United States Forest Service, located at the northeastern Forest Experimental Station at Amherst, Massachusetts, and the representative of the Society of American Foresters, presented a very 
instructive paper on the "Civilian Conservation Corps of the United States Government." This paper was commented on by several members, chief of whom was Mr. Finlayson, who stated that the information given came most opportunely as the federal authorities in this country are giving consideration to the expansion of forestry work for unemployment relief operations in Canada. During the discussion it came out that all United States foresters and forestry school graduates who wanted forestry work could obtain it in connection with the C.C.C. and the question was asked whether Canadians were included in this. The answer was that the technical and supervisory positions were confined to Americans.

As Mr. Rosaire Valin, of the Quebec Forest Service, could not be present, his paper was taken as read.

Mr. K. G. Fensom, of the Canadian Hardwood Bureau, Ottawa, was then asked to present his paper entitled "Some Aspects of Wood Utilization."

The discussion of this was led by Mr. MacElhanney, under whom $\mathrm{Mr}$ Fensom was employed in the Forest Products Laboratories for several years, and he took occasion to congratulate Mr. Fensom on his excellent paper and the fact that he was keeping up with his technical training. Mr. MacElhanney also pointed out that it was his desire, as soon as funds would permit, to include a department in the laboratories which would train foresters for service in the wood-working industries. Cameron asked Dr. Howe if wood. working industries had been approached in regard to summer employment for students. The answer was that there was no encouraging response to his inquiries. Dr. Howe pointed out that classes had been held at the Faculty of Forestry in wood identification for men engaged with wood-using companies, but the attendance in these had dropped off so severely that it was necessary to discontinue them. Fensom pointed out that the wood-using industries do not think they require foresters or technicians and he stated the school and the profession should meet with the industries and be of assistance to each other in this manner. He then mentioned that he proposed to submit a resolution to the resolutions committee on this topic.

R. H. Candy, speaking of Fensom's paper, mentioned the difficulty in disposing of hardwoods, particularly for fuel, and suggested that a bureau or marketing board be set up to make contacts and act as a go-between for the disposal of these products.

Dickson inquired from C. A. Hoar regarding the use of the C.C.C. for ribes eradication and was informed that some camps were engaged in this work and did successful eradication.

Mills then referred to a letter which he sent to the President regarding 
a paid secretary, and the President stated that this matter was receiving consideration and would be dealt with later.

The meeting then adjourned ( 31 present).

Thursday afternoon members of the Society joined with the Woodlands Section of the Canadian Pulp and Paper Association in their open meeting at the Pulp and Paper Research Institute. A list of the papers read at this meeting follows:

"Code Situation in the United States, as it Affects Forest Industries and Conservation." W. R. Brown, Brown Corporation.

"The Civilian Conservation Corps Programme in the United States," Prof. Nelson C. Brown, N.Y. State College of Forestry.

"Co-operation," G. C. Piché, Chief Forester, Dept. of Lands and Forests, Quebec.

Thursday evening the annual dinner of the Society was held in the Blue Room of the Windsor Hotel, with thirty-eight (38) members and guests present. The President, Mr. Piché, acted as toastmaster. After the serving of dinner and some entertainment by local talent the speeches of the evening were proceeded with. The chairman announced that the Hon. H. Mercier, Minister of Lands and Forests for the province of Quebec, who had been announced as the guest speaker, was unable to be present owing to legislative duties at the Capital. It was moved by Dr. Howe and seconded by Elwood Wilson, that the Secretary be instructed to write to Mr. Mercier expressing the regrets of the meeting at his inability to be present.

Before calling on charter members to speak, Mr. Piché, himself a charter member, said that Canadian pulp and paper industries need have no fear of competition from potential newsprint output from the southern States of the Union, where southern pine is being developed as a pulpwood, if laboratory technicians in the industry in Canada progress at the same rate as they have in the past.

Holding out a piece of cellophane which had been wrapped about a cigar, he declared that if technicians in Canada could carry on with the experimental work which had led to the discovery of a by-product of pulp, similar to cellophane, the Dominion's pulp and paper industry would quite safely and confidently "let them make newsprint from southern pine, and let them make it all," while Canada turned out substitutes for many articles of import which cost the country a considerable sum at the present time. He foresaw the time when such products as wool, cotton and many others, now being imported into Canada, would be replaced by the by-products of pulp and as 
the result of brilliant and continued research on the part of Canadian pulp and paper technical experts.

Mr. C. A. Hoar, of the U.S. Forest Service said in part that Canada is in a condition that the United States would like very much to achieve, insofar as her forested lands are concerned. "In Canada you are very fortunate that so much of your forests lie on government property. In our country the government is now ruefully undertaking the unhappy job of buying back great tracts of lands for forestry purposes and some at incredibly low prices. Canada is to be congraulated on her maintenance of government ownership of such a fine natural resource."

Dr. Howe deplored the tragedy of so many young men spending four or five thousand dollars preparing themselves for a profession, and being unable to enter the profession when they graduated. He said that they should be prepared to take any kind of job in the forests, and learn the foundations of the profession while awaiting opportunities for which they were fitted.

Other speakers included E. H. Finlayson, George Boisvert, Messrs. Small and Gibson; E. J. Zavitz, who in a happy vein, traced the trials and tribulations of foresters in Canada in the early years; Elwood Wilson, and others who included in their remarks reminiscences of forestry as it was 25 years ago when the Society was first founded.

Friday morning, January 26th. The meeting opened with the VicePresident, W. A. Delahey, in the chair. The first paper was read by J. R. Dickson, on "Forest Regulation."

Among others, Mr. Ellwood Wilson commented on this paper. He felt that it was timely and to the point in its frank discussion of the all-too-evident spread between forestry precept and woods practice in Canada generally, both on Crown and private lands. He believed that a useful and urgent field for co-operative experiments, as between governments and their lumberman tenants in Canada, lay in logging cost studies. For instance, in selective logging such a time-cost study would help to determine for each region, where the profit and loss line comes in relation to minimum tree size.

Again, Mr. Wilson was inclined to question the statement that the reservation of what has in the past been referred to as "absolute forest land" would today be at all adequate to ensure all essential forest benefits. $\mathrm{He}$ declared that the economic margin-of-cultivation in forest land had for years past been steadily rising, just as in the case of farm land. The latter, however, was emphasized by the abandoned farms to be seen on every hand. He felt that Canada had now a great area of land sub-marginal for forestry use. This was forest land which, because of deterioration from fire, erosion, weathering, or poor drainage, combined with changing economic factors, 
had too low a productive capacity for profitable forest management. This land, of too low site quality for commercial forestry, should be defined and managed as grazing land, or watershed protection forest, or for recreational, park land, or wild fur harvest uses, or for fish and game conservation purposes.

This was followed by Mr. MacElhanney's paper on "Wood as a Fuel in Canada." Mr. Kilby inquired how the use of oil affects the present consumption of coal and wood and it was pointed out that oil was more costly. Dallyn informed the meeting that he had been making a study of this matter for several months and had compared the amount of coal being imported for heating purposes with wood and pointed out that much more wood was being used during the last two or three years than for the same period previously. Candy reminded the meeting that the price of wood increases with distance and that transportation was the greatest problem. He stated further that in his mind the problem could be solved to a great extent in two ways: first, by use of tractors, and second, by building roads by the unemployed to inaccessible parts and thereby bringing out more hardwoods. Lane told of his experience at Lucerne and stated that they had found that thirty miles away from the market was about the limit for shipping wood. Kilby pointed out that the railways during the past year had more cars hauling wood in its different forms than grain. Dallyn took exception to Lane's statement regarding the distance of profitable wood transportation and stated that his investigations show that wood was being shipped profitably in Ontario by railway for a distance of from 80 to 100 miles. Nix stated that there had been a stimulus in wood export from New Brunswick and shipment had been made to Boston by boat.

Professor Gibson stated that the use of wood for fuel at the University of New Brunswick had been increased during the past few years and one building was being heated entirely by wood, and in other buildings it was being used spring and fall. Piche mentioned that the use of wood was on the increase in Quebec and many institutions and small towns were being encouraged in this in order to give work to people in the forest districts. He passed around a poster which had been published for this purpose.

The question of a paid secretary was then brought up and it was pointed out that such a scheme would mean an annual fee of from ten to fifteen dollars for each member. A few members present expressed their willingness to pay such a fee. The Secretary pointed out that the work was becoming too heavy to carry with his regular duties and suggested that the extra work entailed be paid for out of Society funds and that this work be done outside of office hours. Another suggestion was that the work be carried on by 
someone part time, such as a teacher in a forestry school, so that emphasis could be placed on the work during the summer and a certain amount of travelling be done. The matter was left to a committee to be appointed by the President.

The Resolutions Committee then presented its report through the Chairman, Dr. Howe (see separate list of resolutions).

Each resolution was considered separately and voted on. Following the reading of Resolution No. 1 an amendment was moved by Wilson, seconded by Claridge, that this Resolution be laid on the table for one year. Amend. ment lost.

During the discussion of the Resolution the Secretary read a telegram from the British Columbia Section and tabled fifteen unsolicited letters from British Columbia members, all supporting the Executive in the controversy with the Canadian Forestry Association.

There was some further discussion of the Resolution, but it is impossible to give this in detail as no provision was made for a stenographic report of any part of the meetings and many members hesitated from discussing this matter which had been given a great deal of publicity during the summer. The Resolution was passed by a good majority. Wilson then moved that this Resolution be given to the press and also be given fullest possible publicity. No seconder. He then intimated that he would look after this part of it himself.

It was then pointed out that, while the members assembled at the annual meeting spoke for the Society on such matters, it would be only courtesy on the part of this meeting to allow the members who were not present to read this Resolution and make any comments which they cared to before publishing it. The Secretary was instructed to do this and report the result of the canvass in the Chronicle.

The remaining resolutions were all passed with few comments.

Dallyn suggested that Society members should be working on some definite forestry problems. The Secretary then outlined the programme which was inaugurated a few years ago when Mr. Avery was president, and informed the meeting that these reports were being published from time to time as they were received.

Dickson brought up the question of affiliate membership in the British Empire Forestry Association and moved that such membership be applied for at a fee not exceeding $£ 2$. Carried.

There was some further discussion regarding a paid secretary, and it was pointed out that a grant might be received from one of the technical councils 
to help pay such an officer. Others believed that the Society itself should pay the salary, and that the fee should be raised to meet this.

Riley suggested that more time be given to the discussion of business matters at future meetings.

The President then thanked the members for their attendance and wished them success for the future.

The meeting adjourned.

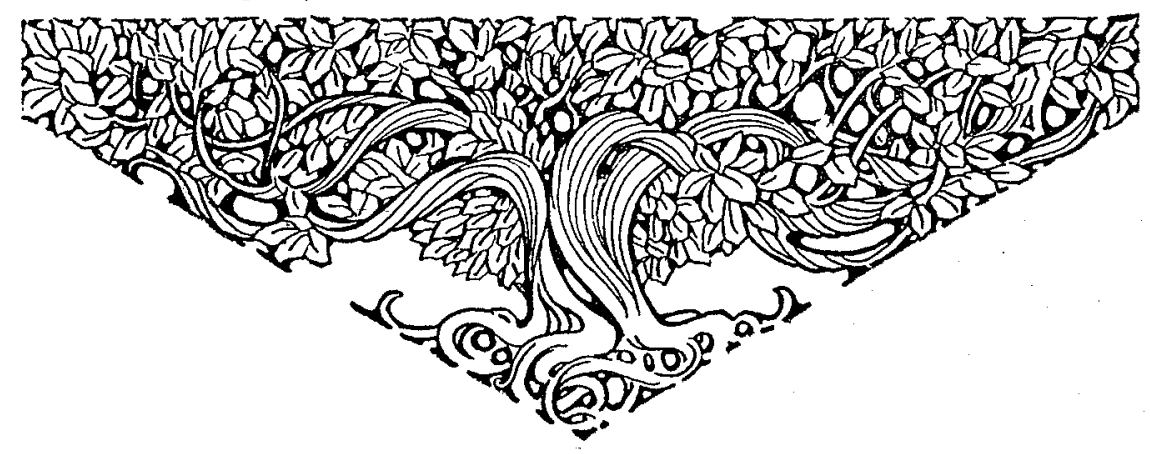

